\title{
PENGARUH PEMBERIAN EKSTRAK ETANOL DAUN BELIMBING WULUH (Averrhoa bilimbi L.) TERHADAP KADAR TRIGLISERIDA PADA TIKUS PUTIH BETINA (Rattus norvegicus)
}

\author{
${ }^{1}$ Yogie Irawan, ${ }^{2}$ Risa Wahyuningsih \\ STIKes Borneo Cendekia Medika Pangkalan Bun \\ 1maasyuduk@gmail.com, \\ risawahyuningsih@gmail.com
}

\begin{abstract}
ABSTRAK
Ekstrak daun belimbing wuluh (Averrhoa bilimbi L.) bertujuan untuk mengetahui pengaruh pemberian terhadap kadar trigliserida pada tikus putih betina (Rattus norvegicus). Tiap-tiap kelompok terdiri dari 5 ekor tikus. Kelompok I (kontrol positif) diberi perlakuan berupa obat Gemfibrozil, CMC-Na 0,5\% dan propiltiourasil 0,1\%. Kelompok II (kontrol negatif) diberikan penambahan CMC-Na 0,5\% dan propiltiourasil 0,1\%, Kelompok III, IV dan V diberikan ekstrak daun belimbing wuluh (Averrhoa bilimbi L.) dengan 3 dosis berturut-turut yaitu : 3,3 mg/200 g bb; 6,6 $\mathrm{mg} / 200 \mathrm{~g} \mathrm{bb}$; dan 13,2 mg/200 g bb, CMC-Na 0,5\% dan propiltiourasil 0,1\%. Untuk kelompok VI (tanpa perlakuan) Semua tikus diperiksa kadar trigliserida darahnya sebelum dan setelah masa perlakuan selama 21 hari kemudian hasil selisih kadar trigliserida pret test dan post test dianalisis menggunakan uji Anova dan uji post hoc. Hasil analisis menunjukan terdapat perbedaan signifikan $(\mathrm{p}<0,05)$ antara kelompok kontrol negatif dengan kelompok kontrol positif namun tidak menunjukkan perbedaan yang signifikan secara statistik untuk kelompok dosis I, II, III dan VI sehingga Ekstrak daun belimbing wuluh tidak dapat memberikan pengaruh yang besar terhadap penurunan kadar trigliserida darah pada tikus putih betina (Rattus norvegicus).
\end{abstract}

Kata kunci : ekstrak daun belimbing wuluh, trigliserida, tikus putih

THE INFLUENCE OF WULUH (Averrhoa bilimbi L.) ETHANOL EXTRACT ON TRIGLICERIDE LEVELS IN RICE WHITE RATS (Rattus norvegicus)

\begin{abstract}
Starfruit leaf extract (Averrhoa bilimbi L.) refers to triglyceride levels in female white rats (Rattus norvegicus). Each group consists of 5 mice. Group I (positive control) was named consisting of the drug Gemfibrozil, CMC-Na $0.5 \%$ and propyltiouracil $0.1 \%$. Group II (negative control) was given 0.5\% CMC-Na and $0.1 \%$ propyltiouracil, Group III, IV and V were given starfruit leaf extract (Averrhoa bilimbi L.) with 3 doses provided accordingly: $3.3 \mathrm{mg} / 200 \mathrm{~g} \mathrm{bb;} 6.6 \mathrm{mg} / 200 \mathrm{~g} \mathrm{bb}$; and $13.2 \mathrm{mg} / 200 \mathrm{~g} \mathrm{BW}$, CMC-Na $0.5 \%$ and propylthiouracil 0.1\%. For group VI (without training) All mice checked triglyceride levels before and after the maintenance period for 21 days then the results of the difference in pretest and posttest triglyceride levels were carried out
\end{abstract}


using the Anova test and post hoc test. The results of the analysis showed a significant difference ( $p<0.05$ ) between the negative control group and the positive control group but did not show a significant difference for the statistics of groups I, II, III and VI so that the starfruit leaf extract could not give a large result to a decrease in triglyceride levels blood in female white mice (Rattus norvegicus).

Keywords: starfruit leaf extract, triglycerides, white mice

\section{PENDAHULUAN}

Menurut WHO (2014), penyebab kematian terbanyak di dunia pada tahun 2012 ialah penyakit tidak menular seperti penyakit kardiovaskular. Berbagai intervensi dan pengobatan telah dikembangkan untuk mengobati penyakit ini. Mulai dari penggunaan obat untuk menurunkan kadar kolesterol, penyakit kardiovaskular serta memiliki fungsi antioksidan (Azuma et al., 2009). Penurunan kadar trigliserida dalam darah dapat dilakukan dengan terapi farmakologis maupun terapi non farmakologis (Anwar 2004). Obatobatan penurun kadar trigliserida memiliki berbagai efek samping, seperti flushing, hiperglikemia, hiperurisemia, hepatotoksik, miopati, dll (U.S. Departement of Health and Human Services 2001). Saat ini, terapi herbal sedang populer di kalangan masyarakat karena dinilai sebagai pengobatan yang mempunyai efek samping sedikit, murah, dan mudah didapat (Khikmawati 2009). Salah satu tanaman di Indonesia yang berkhasiat sebagai obat adalah blimbing wuluh (Averrhoa bilimbi).

Tanaman belimbing wuluh memiliki kandungan kimia yaitu kalium oksalat, flavonoid, pektin, tanin, asam galat dan asam ferulat (Soedibyo 1998). Flavonoid memiliki berbagai potensi bagi kesehatan (Halliwell 2005) Penelitian yang dilakukan pada tahun 1996 di Finland menyebutkan bahwa flavonoid dapat menurunkan angka kejadian penyakit kardiovaskular (Knekt 1996) Flavonoid meningkatkan aktivitas lipoprotein lipase sehingga berpengaruh terhadap kadar trigliserida serum (Sudheesh 1997). Selain flavonoid, tanin juga diketahui dapat memacu metabolisme glukosa dan lemak, sehingga timbunan kedua sumber kalori ini dalam darah dapat dihindari. Artinya kolesterol dan gula darah turun (Kurnia et al. 2010).

Dosis yang digunakan pada penelitian ini mengacu pada dosis yang pernah dipakai, yaitu dosis buah belimbing wuluh yang digunakan pada penelitian anti hiperlipidemia sebesar $125 \mathrm{mg} / \mathrm{kg}$ yang efektif dalam menurunkan lipid (Ambili et al. 2008). Peneliti menggunakan dosis buah belimbing wuluh karena kandungan yang terdapat pada buah belimbing wuluh hampir sama dengan kandungan yang terdapat pada daun belimbing wuluh. Penelitian ini bertujuan untuk mengetahui potensi dan dosis optimal ekstrak daun belimbing wuluh 
(Averrhoa bilimbi) dalam menurunkan kadar trigliserida pada tikus putih.

\section{METODE PENELITIAN}

\section{Bahan dan Alat}

Bahan yang digunakan adalah daun belimbing wuluh (Averrhoa bilimbi L.) dan Hewan uji yang digunakan adalah tikus putih betina galur wistar yang berumur 2-3 bulan dengan berat 150-200 g. Bahan kimia yang digunakan adalah etanol $70 \%$, kontrol negatif yang digunakan adalah CMC $\quad \mathrm{Na} \quad 0,5 \%, \quad$ obat antihipertrigliseridemia gemfibrozil sebagai kontrol positif dan larutan propiltiurasil (PTU) 0,01\%.

Alat yang digunakan untuk maserasi adalah botol coklat, kain flanel, kertas saring, batang pengaduk dan gelas ukur, kandang tikus, tempat makan dan minum, sonde lambung, batang pengaduk, tabung sentrifuge, gelas ukur, spuit injeksi $1 \mathrm{ml}$, rotary evaporator, blender, oven, Spektrofotometer.

\section{Jalannya Penelitian}

Pengeringan bahan dan

Pembuatan serbuk Daun belimbing wuluh sebanyak 2900 gram kondisi basah dikeringkan pada suhu $\pm 50^{\circ} \mathrm{C}$ dan diperoleh 970 gram daun kering (rendemen 33,45\%). Pengeringan dijaga pada suhu $50^{\circ} \mathrm{C}$ dalam oven. Daun belimbing wuluh yang telah dikeringkan tersebut segera diserbukkan dengan mesin penyerbuk dan kemudian diayak sampai derajat halus dengan menggunakan ayakan no.60. Serbuk hasil ayakan ini dinamakan serbuk simplisia daun belimbing wuluh yang kemudian digunakan untuk penyarian.

\section{Penetapan Susut Pengeringan}

Serbuk Daun Belimbing Wuluh Pada penelitian ini kadar air diperiksa dengan menggunakan alat moisture balance.

Tabel 1. Hasil penetapan susut pengeringan dalam serbuk daun belimbing wuluh

\begin{tabular}{cc}
\hline Berat serbuk (g) & $\begin{array}{c}\text { Susut } \\
\text { pengeringan }(\% \\
\mathbf{b} / \mathbf{b})\end{array}$ \\
\hline 1,00 & 5,9 \\
1,01 & 6,9 \\
1,03 & 8,7 \\
\hline Rata-rata + SD & $\mathbf{7 , 1 6}+\mathbf{0 , 3 3}$
\end{tabular}

Hasil data tabel diatas terdapat penetapan susut pengeringan serbuk daun belimbing wuluh yang ditimbang sebanyak 1 gram kemudian dilakukan pengukuran susut pengeringan. Waktu yang diperlukan dalalm pengukuran adalah 45 menit untuk setiap penetapan, kemudian susut pengeringan dihitung dalam satuan persen (\%). Prosentase rata-rata susut pengeringan dalam serbuk daun belimbing wuluh adalah $7,16 \% \pm 0,33$.

\section{Hasil Pembuatan Ekstrak Etanol Daun Belimbing Wuluh Ekstrak daun belimbing wuluh diperoleh dari hasil maserasi yang proses penguapannya dilakukan menggunakan rotary evaporator. Serbuk daun belimbing wuluh ditimbang $900 \mathrm{~g}$, dimasukkan kedalam bejana kemudian ditambahkan pelarut etanol $70 \%$ sebanyak $9000 \mathrm{ml}$. Proses maserasi dilakukan selama $5 \times 24$ jam, campuran tersebut harus sesekali}




$\begin{array}{ll}\text { dikocok minimal } 3 \text { kali sehari, } & \text { dan dikocok } \\ \text { kemudian disaring menggunakan kain } & \text { lagi } \\ \text { flanel kemudian dilanjutkan dengan } & \text { kemudian } \\ \text { kertas saring kemudian dipekatkan } & \text { disaring lalu } \\ \text { menggunakan evaporator pada suhu di } & +\mathrm{Mg} 0,2 \mathrm{~g} \\ \text { bawah } 70^{\circ} \mathrm{C} \text { sampai mendapatkan } & \text { dan } 3 \text { tetes } \\ \text { ekstrak kental. Kemudian ekstrak kental } & \mathrm{HCl} \text { pada } \\ \text { ditimbang untuk menghitung prosentase } & \text { masing- } \\ \text { rendemen ekstrak daun belimbing } & \text { masing } \\ \text { wuluh. Hasil ekstrak kental etanol yang } & \text { filtrate }\end{array}$

didapatkan dari 500 gram serbuk adala

112,96 gram dengan rendemen $12,55 \%$.

Data pembuatan ekstrak etanol daun belimbing wuluh dapat dilihat pada tabel 3.

Saponin Ekstrak + air Terbentuk Terbentuk

Tabel 2. Hasil rendemen ekstrak etanol daun belimbing wuluh

panas $10 \mathrm{ml}$, buih yang buih yang

didinginkan stabil stabil

lalu dikocok setinggi 1 setinggi 1

kuat-kuat sampai 10 sampai 10

selama $10 \quad \mathrm{~cm}+1 \quad \mathrm{~cm}+1$ tetes

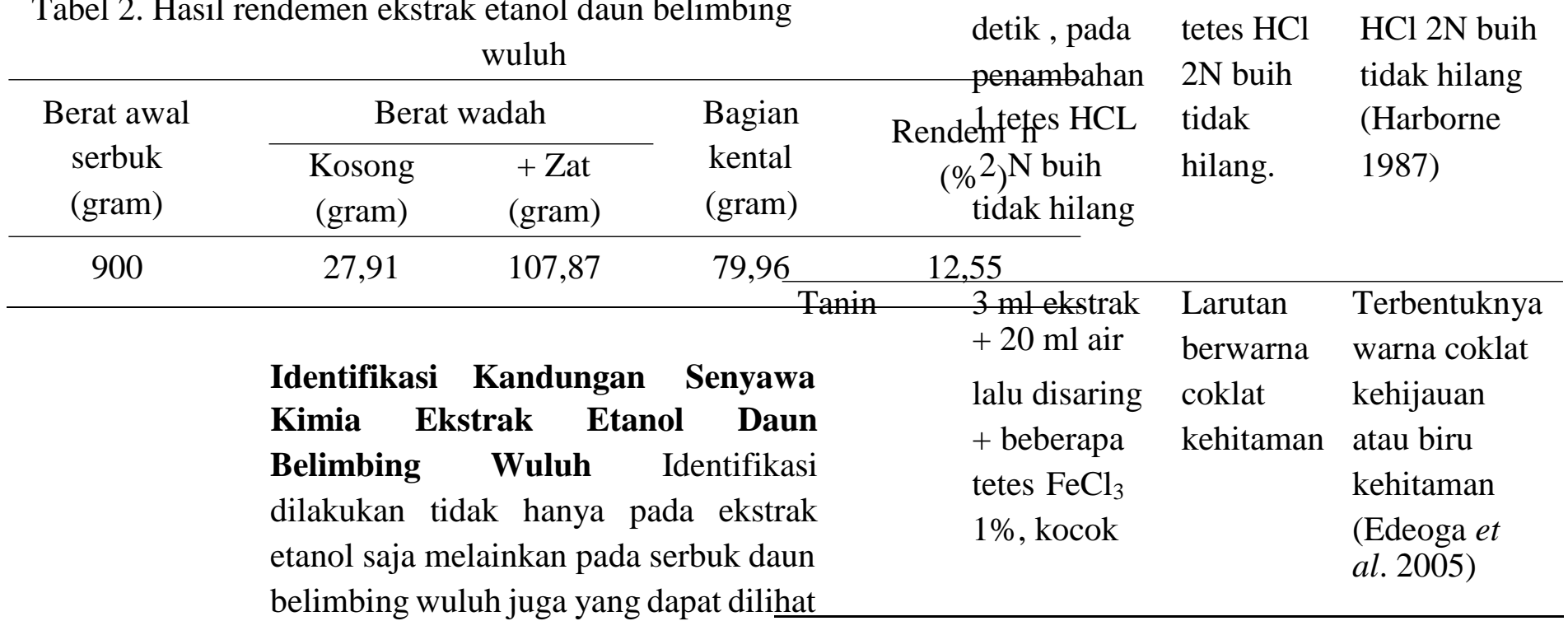

pada tabel di bawah ini.

Dari hasil uji identifikasi kandungan senyawa menunjukkan

Tabel 3. Hasil identifikasi kandungan senyawa bahwa ekstrak etanol $70 \%$ daun ekstrak etanol daun belimbing wuluh belimbing wuluh dan serbuk daun belimbing wuluh mengandung

\begin{tabular}{llllll}
\hline Senyawa & Prosedur & Hasil & \multicolumn{2}{c}{ Pustaka flavonoid, saponin, dan tanin. Hal ini } \\
Flavonoid & $5 \mathrm{ml}$ ekstrak & Larutan & merah/ & dapat diketahui & dengan \\
& $+5 \mathrm{ml}$ & berwarna & jingga/ & membandingkan hasil uji kualitatif yang \\
& etanol & merah & kuning padadiakukan dengan pustaka. \\
dikocok, & & lapisan amil \\
dipanaskan, & & alkohol & Pembuatan Kontrol Negatif dan \\
& & & & Kontrol Positif Kontrol negatif dan
\end{tabular}


kontrol positif merupakan pembanding untuk mengetahui adanya pengaruh pada hewan uji. Kontrol negatif yang digunakan adalah larutan CMC 0,5\% yang juga digunakan sebagai suspending agent. Sedangkan kontrol positif yang digunakan adalah gemfibrozil. Dosis gemfibrozil yang digunakan pada manusia dengan berat $70 \mathrm{~kg}$ untuk terapi hipertrigliseridemia adalah 0,6-1,2 g/hari (Katzung 2001). Peneliti menggunakan dosis efektif manusia yaitu 1,2 $\mathrm{g} / \mathrm{hari}$ atau 1200 $\mathrm{mg} /$ hari yang kemudian dikonversi ke dosis tikus. Tablet gemfibrozil $600 \mathrm{mg}$ dihaluskan menjadi serbuk, kemudian dibuat suspensi dalam aquades $100 \mathrm{ml}$ dan ditambahkan CMC 1\% secukupnya agar serbuk tidak cepat mengendap. Jadi $1 \mathrm{ml}$ suspensi mengandung $6 \mathrm{mg}$ gemfibrozil. Dosis ditentukan berdasarkan angka konversi dari berat badan manusia $70 \mathrm{~kg}$ ke tikus dengan berat badan $200 \mathrm{~g}$ adalah 0,018, diperoleh dosis $0,018 \mathrm{~g} / 200 \mathrm{~g}$ berat badan tikus/hari atau setara dengan 0,18 $\mathrm{mg} / 200 \mathrm{~g} \mathrm{bb}$, kemudian dosis untuk hewan uji dihitung berdasarkan berat badan masing-masing.

\section{HASIL DAN PEMBAHASAN}

\section{Hasil selisih rerata kadar trigliserida} darah tikus putih (Rattus norvegicus) post test dan pre test pada kelompok yang diberi obat gemfibrozil (kontrol positif) jauh lebih rendah dibanding kelompok kontrol negatif.

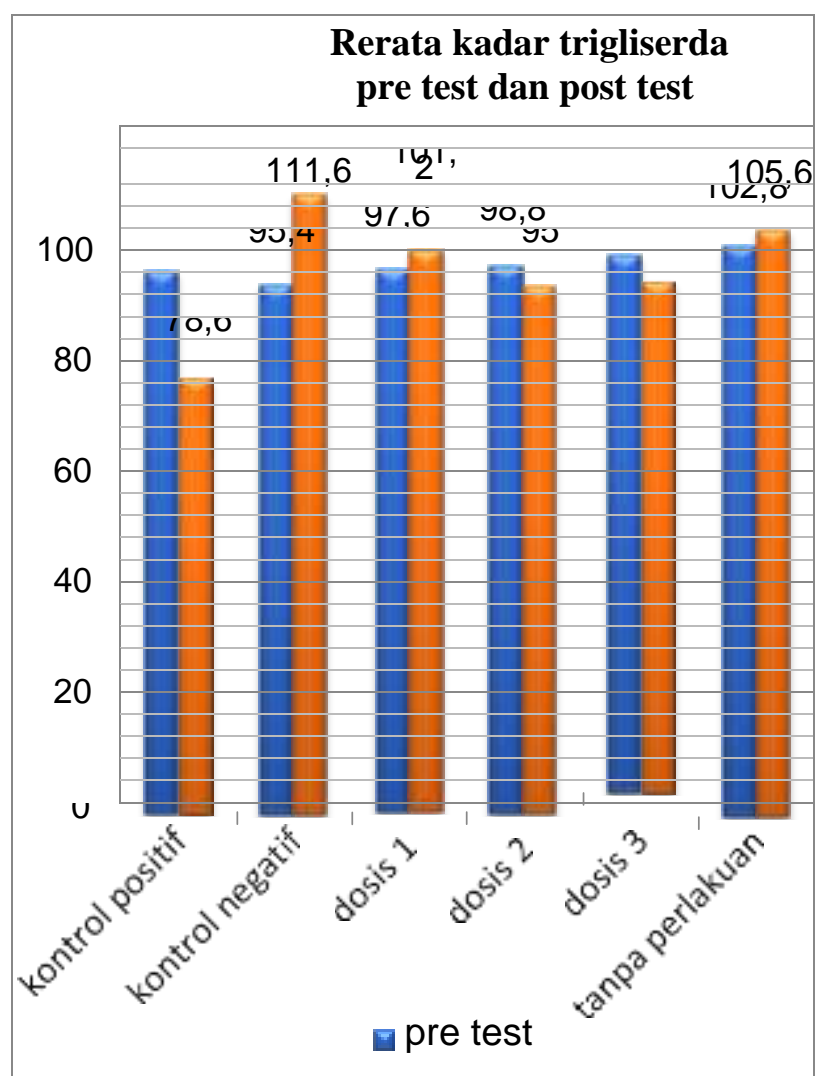

\section{Gambar 1. Histogram rerata kadar}

trigliserida tikus putih pre test dan

\section{post test $(\mathrm{mg} / \mathrm{dl})$.}

Data selisih rerata kadar trigliserida darah tikus putih (Rattus norvegicus) post test dan pre test pada kelompok yang diberi obat gemfibrozil (kontrol positif) jauh lebih rendah dibanding kelompok kontrol negatif. Hal ini membuktikan bahwa pemberian gemfibrozil dapat menurunkan kadar trigliserida darah tikus putih (Rattus norvegicus) secara signifikan dibandingkan kelompok yang tidak diberi obat tersebut. Pemberian ekstrak daun belimbing wuluh dosis I tidak dapat menurunkan kadar trigliserida sedangkan dosisi II dan III dapat menurunkan kadar trigliserida darah tikus putih (Rattus norvegicus) tetapi 
penurunannya tidak signifikan yaitu ( $\mathrm{p}=0,366$ dan $\mathrm{p}=0,296)$. Selisih kadar trigliserida pre test dan post test terbesar terdapat pada kontrol positif yang berarti daya antihipertrigliseridemia gemfibrozil tetap lebih besar dibandingkan kelompok daun belimbing wuluh dosis III sekalipun. Padahal data deskriptif kadar pre test kelompok daun belimbing wuluh dosis III lebih rendah $1 \mathrm{mg} / \mathrm{dl}$ dibandingkan kelompok gemfibrozil, tetapi penurunannya tetap tidak bisa melebihi penurunan gemfibrozil. Perbedaan pengaruh efektivitas gemfibrozil dibandingkan ekstrak etanol daun belimbing wuluh dapat pula dipengaruhi perbedaan mekanisme kerja keduanya. Gemfibrozil bekerja melalui peningkatan bersihan VLDL diperantarai LPL, sedangkan ekstrak daun belimbing wuluh melalui aktivitas flavonoid,tanin dan saponin.

Dari hasil uji normalitas menggunakan uji Kolmogorov-Smirnov untuk mengetahui apakah data yang diperoleh mempunyai distribusi yang normal yang berarti mempunyai sebaran data yang normal sehingga dapat dianggap mewakili populasi . Dari data yang diperoleh menunjukkan nilai $\mathrm{p}=0,059(\mathrm{p}>0,05)$ pada semua kelompok dan menunjukan terdapat perbedaan signifikan $(\mathrm{p}<0,05)$ antara kelompok kontrol negatif dengan kelompok kontrol positif. Sedangkan dosis I, dosis II, dosis III dan kelompok tanpa perlakuan tidak menunjukkan perbedaan yang signifikan secara statistik. Ekstrak daun belimbing wuluh dosis III (13,2 mg/200 gram BB/hari) merupakan dosis efektif tertinggi diantara ketiga dosis tersebut. Rendahnya daya antihipertrigliseridemia yang ditimbulkan oleh ekstrak daun belimbing wuluh diduga karena rentang dosis terlalu kecil dan tidak dilakukannya orientasi dosis sebelumnya, sehingga pada dosis tersebut ekstrak daun belimbing wuluh tidak menunjukkan penurunan kadar trigliserida yang signifikan.

Dengan hasil tersebut, maka data selisih kadar trigliserida pre test dan post test memenuhi syarat untuk di uji menggunakan ANOVA untuk mengetahui ada tidaknya perbedaan rerata selisih kadar trigliserida yang bermakna pada keenam kelompok tersebut. Hasil uji ANOVA menunjukkan $\mathrm{p}=0,009 \quad(\mathrm{p}<\quad 0,05)$ sehingga dapat dikatakan terdapat perbedaan selisih rerata kadar trigliserida yang signifikan diantara keenam kelompok.

\section{KESIMPULAN}

Pemberian ekstrak daun belimbing wuluh (Averrhoa bilimbi L.) dengan dosis $3,3 \mathrm{mg} / 200$ gram $\mathrm{BB} / \mathrm{hari}$, $6,6 \mathrm{mg} / 200$ gram BB/hari dan dosis 13,2 $\mathrm{mg} / 200$ gram $\mathrm{BB} / \mathrm{hari}$ tidak dapat memberikan pengaruh yang besar terhadap penurunan kadar trigliserida darah pada tikus putih betina (Rattus norvegicus) dan tidak terdapat perbedaan pengaruh yang signifikan.

\section{DAFTAR PUSTAKA}

Anwar, T.B. 2004. Dislipidemia sebagai Faktor Resiko Penyakit Jantung 
Koroner.

http://library.usu.ac.id/downloa d/fk/gizi-bahri3.pdf (12 April 2012)

Halliwell Barry, Joseph Rafter, Andrew Jenner.Dietary Polyphenols and Health: Proceeding of the International Conference on Polyphenols and Health. American Journal of Clinical Nutrition. 2005; 81(1): 215S$217 \mathrm{~S}$

Knekt P, Jarvinen R, Reunanen A, Maatela J. Flavonoid intake and Coronary Mortality in Finland: a Cohort Study. BMJ 312:478-481, 1996

Kurnia Y, Afifah N, Mustofa A. 2010.

pengaruh pemberian air rebusan daun pare

(Momordica charantia L.) terhadap kadar kolesterol total serum darah tikus putih (Rattus norvegicus) dengan induksi hiperkolesterolemia [Karya Tulis Ilmiah]. Surakarta: Universitas Sebelas Maret.

Sudheesh, S, G. Pressankumar, S. Vijayakumar and N.R. Vijayalashmi. 1997. Hypolipidemic Effect of Flavonoids from Solanum Melongena. Plant Foods for Human Nutrition, 51: 32130 . 